
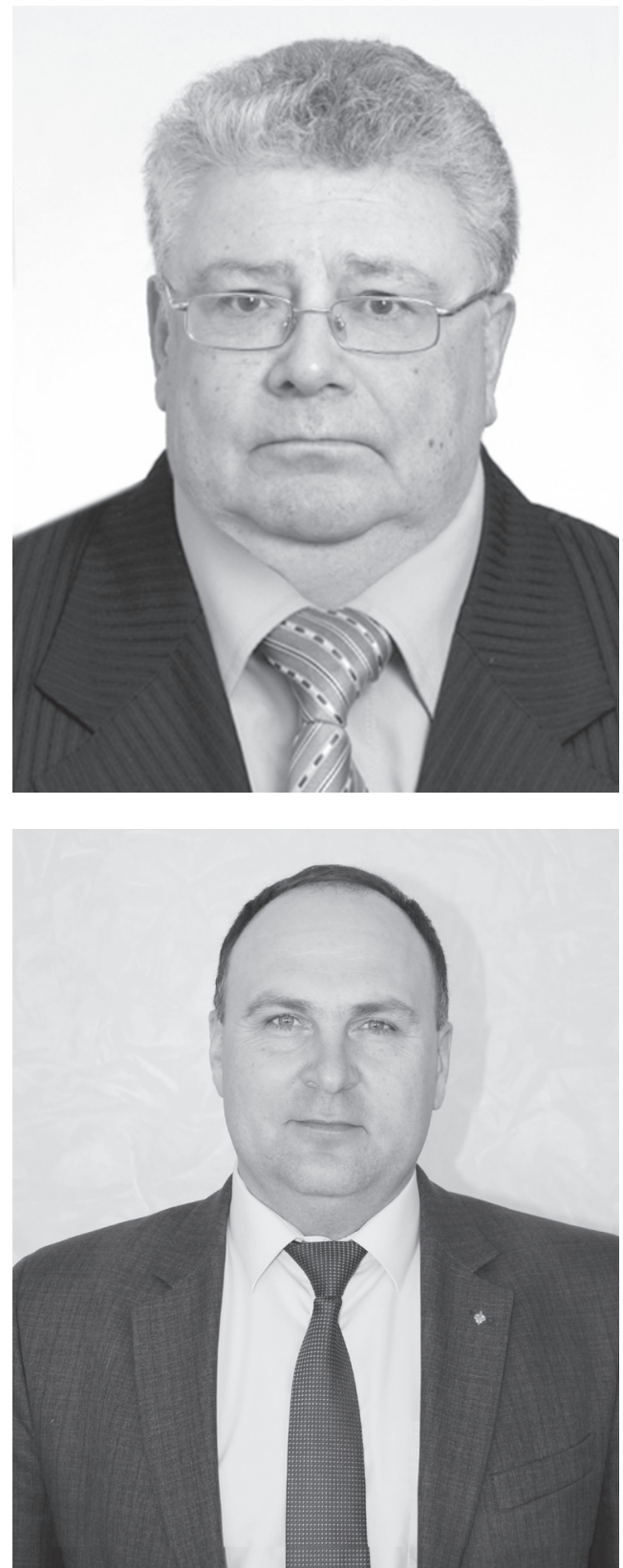

Піддубний Михайло Іванович,

аспірант кафедри суспільного розвитку та суспільно-владних відносин, Національна академія державного управління при Президентові України, м. Київ, вул. А. Цедіка, 20, mел.067 4339107, e-mail: piddubnym@gmail.com

ORCID: 0000-0003-4682-1376 
Поддубный Михаил Иванович,

аспирант кафедры общественного развития и общественно-властных отношений, Национальная академия государственного управления при Президенте Украины, г. Киев, ул. А. Цедика, 20 тел. 067 4339107, e-mail:piddubnym@gmail.com

ORCID: 0000-0003-4682-1376

\section{ARCHETYPICAL ANALYSIS OF THE NATIONAL AWARENESS AND PATRIOTISM OF YOUTH IN MODERN UKRAINE: ON THE EXAMPLE OF THE PUBLIC ORGANIZATION "PLAST"}

Abstract. The article analyzes an archetypal analysis of national identity and patriotism of youth in modern Ukraine. The essence of the concept of national self-consciousness, which is defined as a holistic self-reflection of a nation (comprehensive understanding of the nation of its historical civilization vocation), is revealed. National consciousness acts as a powerful means of its historical progress, full functioning in the world community, promotes the collective human will to an active life position, mobilization of all available and hidden vital resources of the people.

The urgency of national-patriotic education of citizens, especially young people, is conditioned by the process of consolidation and development of Ukrainian society, the current challenges facing Ukraine and require further improvement of the system of national-patriotic education, optimization of state policy in this area.

Youth organization "Plast" occupies a special place in the national-patriotic upbringing of youth. "Plast" - the national scout organization of Ukraine is a nonpolitical and non-confessional youth organization. The aim of Plast is to promote comprehensive, patriotic education and self-education of Ukrainian youth by conscious, responsible and full-fledged citizens of local, national and world communities, community leaders on the ideals of "Plast" and on the principles of Christian morality.

One of the main tasks of the modern Plast movement is the development of human potential, the education of a creative, thinking generation of a new formation, new leaders, reformers and statesmen. The basis of the system of national-patriotic education is the idea of the development of Ukrainian statehood as a consolidating factor in the development of society and the nation as a whole. Forms and methods of education are based on archetypes of Ukrainian folk traditions, the best achievements of national and world pedagogy and psycho$\log$.

Keywords: national self-consciousness, patriotism, archetype, archetype analysis, patriotic education of youth, youth organization "Plast". 


\section{АРХЕТИПОВИЙ АНАЛІЗ НАЦІОНАЛЬНОЇ САМОСВІДОМОСТІ І ПАТРІОТИЗМУ МОЛОДІ В СУЧАСНІЙ УКРАЇНІ: НА ПРИКЛАДІ ГРОМАДСЬКОЇ ОРГАНІЗАЦІї “ПЛАСТ”}

Анотація. Проаналізовано архетиповий аналіз національної самосвідомості і патріотизму молоді в сучасні Україні. Розкрито сутність поняття національна самосвідомість, яка визначається як цілісна саморефлексія нації (всебічне розуміння нацією свого історично-цивілізаційного покликання). Національна самосвідомість виступає могутнім засобом іi історичного поступу, повноцінного функціонування у світовій спільноті, спонукає колективну людську волю до активної життєвої позиції, мобілізації всіх наявних і прихованих життєвих ресурсів народу.

Актуальність національно-патріотичного виховання громадян, особливо молоді, зумовлюється процесом консолідації та розвитку українського суспільства, сучасними викликами, що стоять перед Україною і вимагають дальшого вдосконалення системи національно-патріотичного виховання, оптимізації державної політики у зазначеній сфері.

Особливе місце у національно-патріотичному вихованні молоді займає молодіжна організація “Пласт”. Це національна скаутська організація України, яка є неполітичною і позаконфесійною молодіжною організацією. Мета "Пласту" - сприяти всебічному, патріотичному вихованню та самовихованню української молоді на свідомих, відповідальних і повновартісних громадян місцевої, національної та світової спільнот, провідників суспільства на ідейних засадах “Пласту” та на засадах християнської моралі.

Одним з головних завдань сучасного пластунського руху є розвиток людського потенціалу, виховання креативного, мислячого покоління нової формації, нових лідерів, реформаторів та державотворців. В основу системи національно-патріотичного виховання покладено ідею розвитку української державності як консолідуючого чинника розвитку суспільства й нації загалом. Форми й методи виховання грунтуються на архетипах українських народних традицій, кращих надбаннях національної та світової педагогіки та психології.

Ключові слова: національна самосвідомість, патріотизм, архетипіка, архетиповий аналіз, патріотичне виховання молоді, молодіжна організація "Пласт".

\section{АРХЕТИПИЧЕСКИЙ АНАЛИЗ НАЦИОНАЛЬНОГО САМОСОЗНАНИЯ И ПАТРИОТИЗМА МОЛОДЕЖИ В СОВРЕМЕННОЙ УКРАИНЕ: НА ПРИМЕРЕ ОБЩЕСТВЕННОЙ ОРГАНИЗАЦИИ “ПЛАСТ”}

Аннотация. Представлен архетипический анализ национального самосознания и патриотизма молодежи в современной Украине. Раскрыта сущность понятия национальное самосознание, которая определяется как целостная саморефлексия нации (всестороннее понимание нацией своего 
историко-цивилизационного призвание). Национальное самосознание выступает мощным средством ее исторического развития, полноценного функционирования в мировом сообществе, побуждает коллективную человеческую волю к активной жизненной позиции, мобилизации всех имеющихся и скрытых жизненных ресурсов народа.

Актуальность национально-патриотического воспитания граждан, особенно молодежи, обусловлена процессом консолидации и развития украинского общества, современными вызовами, стоящими перед Украиной и требующими дальнейшего совершенствования системы национально-патриотического воспитания, оптимизации государственной политики в указанной сфере.

Особое место в национально-патриотическом воспитании молодежи занимает молодежная организация “Пласт”. Это национальная скаутская организация Украины, которая является неполитической и внеконфессиональной молодежной организацией. Цель “Пласта” - содействие всестороннему, патриотическому воспитанию и самовоспитанию украинской молодежи на сознательных, ответственных и полноценных граждан местного, национального и мирового сообщества, лидеров общества на идейных основах "Пласта” и на принципах христианской морали.

Одной из главных задач современного пластунского движения является развитие человеческого потенциала, воспитание креативного, мыслящего поколения новой формации, новых лидеров, реформаторов и государственных деятелей. В основу системы национально-патриотического воспитания положена идея развития украинской государственности как консолидирующий фактор развития общества и нации в целом. Формы и методы воспитания базируются на архетипах украинских народных традиций, лучших приобретениях национальной и мировой педагогики и психологии.

Ключевые слова: национальное самосознание, патриотизм, архетипика, архетипический анализ, патриотическое воспитание молодежи, молодежная организация “Пласт”.

Problem statement. The formation of a democratic, social, legal state in the direction of sustainable development is possible provided that the agents of qualitative changes in the country are patriotic, professional, nationally conscious people with leadership qualities and skills.

The relevance of national-patriotic education of citizens, especially young people, is predetermined by the process of consolidation and development of Ukrainian society, modern challenges facing Ukraine and require further improvement of the system of nationalpatriotic education, optimization of state policy in this area.

In Ukraine, the national-patriotic education of young people should become one of the priorities of the state 
and society for the development of the citizen as a highly moral person who cherishes Ukrainian traditions, spiritual values, with appropriate knowledge, skills and abilities, is able to implement its potential in modern society, professes European values, ready to fulfill the duty to protect the Fatherland, independence and territorial integrity of Ukraine. And this education (among other approaches) should be based on the archetypes of the past, historical memory and traditions of the Ukrainian people.

Analysis of recent publications on the subject and identification of previously unsolved parts of the overall problem. The theoretical basis for understanding the mechanisms of formation and implementation of the state policy of national-patriotic education of young people were studied in the works of such scientists as V. Alekseiev, E. Afonin, V. Bakumenko, M. Holovatyi, V. Kniaziev, V. Koval, Yu. Kuts, N. Perepelytsia, A. Popok, V. Rebkalo, T. Seniushka, Yu. Surmin, S. Teleshun, V. Troschynskyi, L. Chuprii and others. The importance of national trends in the education of youth was stressed by Ukrainian officials, teachers, H. Vasjchenko, B. Hrinchenko, M. Hrushevskyi, O. Dukhnovych, M. Drahomanov, I. Ohienko, V. Sukhomlinskyi, and the like.

Despite the importance of these studies, they focus only on the need for the formation of patriotic values among young people, leaving without considering all the variety of ways of national-patriotic education.

The purpose of the article is to conduct an archetypal analysis of the formation and implementation of the main structural units of the national consciousness of young people and the ways of its management impact on the development of national consciousness: from the worldview through morality - to ideology and further through politics - to the way of life of people [1].

Presentation of the main material of the study. Recently, a lot of scientific research has been devoted to the archetypes of the unconscious. At the heart of these scientific works the problems of national consciousness and Patriotic education based on the study of archetypes, folk traditions and the like were researched. Archetypes here perform the function of social memory, contain the knowledge and experience of the people. "The uniqueness of the archetype is that it arises not only in the context of the wise past, but also helps to build the guidelines of the modern" [2, p. 23].

The problem of self-consciousness has interested mankind since ancient times. Socrates formulated it as a philosophical credo, cognitive imperative "Know yourself!". Such knowledge was for him not only a means of satisfying human curiosity, but above all a basis for solving the question of the moral imperatives of human activity. For example, the category of "duty", developed in ancient times, becomes the cornerstone of moral consciousness throughout the history of mankind, and today the interpretation of its content in the context of practical and spiritual experience accumulated by mankind remains one of the central worldview problems [3].

In this regard, it is appropriate to pay attention to a more detailed typo- 
logy of the category of self-consciousness.

Depending on the subject, which acts as a carrier of self-consciousness, it can be individual (personal) or collective (self-consciousness of a certain group of people, objectively or consciously united in a certain community: family, clan, class, professional group, religion, party, nation and the like). Consequently, we can talk about the presence of various forms of self-consciousness (individual and collective) and its various types: personal, generic, professional, class, religious, ethnic, national, universal and the like.

A person can be a carrier of almost all kinds of self-consciousness at the same time. Moreover, the formation of self-consciousness of the individual occurs as a result of the integration of a number of its self-meanings in various sections and areas of reality, living space, that is, as a generalized result of individual, social, professional, political, religious, national, etc. self-identification. For a holistic view of himself, the individual must be aware of his attitude to the greatest possible number of existing values and relationships in society. Depending on the circumstances and needs, one type of self-identification gives way to or coexists with another. The rest of the time remains in the shadows, does not play a leading or even significant role in the life. Among the numerous self-determination of a person, national self-identification occupies a prominent place, which in its developed form appears as national self-consciousness. This is due to the fact that the nation for modern man remains the most vital, fundamental historical community.
National identity as a consequence of the historical genesis of the nation at the same time is a necessary condition for its full development and progress. The essence of national consciousness is defined as a holistic self-reflection of the nation (a comprehensive understanding of the nation's historical and civilizational vocation). National consciousness is a powerful means of its historical development, full functioning in the world community, encourages the collective human will to an active life position, mobilization of all available and hidden vital resources of the people. Such an understanding we find in D. Dontsov: "Millions of divergent human wills are united in one - "joint triumphs in the past", "glory of ancestors", then - a common will in the present and "readiness for further major cases, one big goal for all in the future", one big enterprise that would unite under its slogan all enthusiasm, all fanaticism, all the burning of millions, tearing them in critical moments of life beyond their everyday worries and egoisms towards one great goal" [4]. p. 225], which are not able to replace any mercantile calculations, material benefits and the like. However, this latter is not always a reliable support for national development, because they are easily transformed by the fluctuation of economic and sociopolitical conditions on the brake of national development, and even on its crushing and destructive force. But, the patriotism generated by national consciousness practically do not depend on the financial situation of the nation. Moreover, in our opinion, the deterioration of living conditions, the threat to national progress or independence, other such negative phenomena stimu- 
late the spiritual energy of a nationally conscious citizen, and therefore cause a surge of his patriotic activities.

Patriotic consciousness of the person is a complex holistic education, which combines a set of knowledge about the actual genetic roots, understanding of social reality, trends and prospects of its development, the establishment of readiness for creative activity and protection of the Fatherland as the predominant motive of life in the context of the prospects of their own existence. The study of the problems of Patriotic consciousness has a number of aspects:

a) philosophical and patriotic consciousness as a source of personal activity in the actual and potential environment of life;

b) psychological - patriotic consciousness, as the level of mental life of the individual, which reflects the uniqueness of the social world and is expressed in the development of regulators of behavior, social relations and human activities aimed at creating the power of the Fatherland, and provide readiness for extreme conditions of protection of the Motherland;

c) sociological - patriotic consciousness as a set of orientation, interests, representations of people United in social groups, which are differentiated on various grounds, in relation to the interests of society as a whole, state policy, international relations, personal prospects of life and their determinants [5].

Structurally, substantively and functionally, any social (including national) self-consciousness of an individual is a complex system that includes a huge number of elements and their connections. In its historical development, it goes a long way of self-improvement from elementary ideas, stereotypes and norms to a highly developed holistic system of beliefs and values. The main content of the structural elements of national consciousness is determined by the functions that it performs in public life. There are three main functions: cognitive, value, regulatory (see Figure).

Archetypes of national consciousness of the person in relation to the person and society:

- stimulation of self-knowledge, self-reflection, from finding the point of reference and spiritual source of selfcreation;

- knowledge of national and cultural traditions of a kind and people, awareness of the social significance of their own activities and the meaning of life in general;

- formation of the spiritual basis and wisdom of life-a sense of civic duty and personal responsibility to previous and future generations;

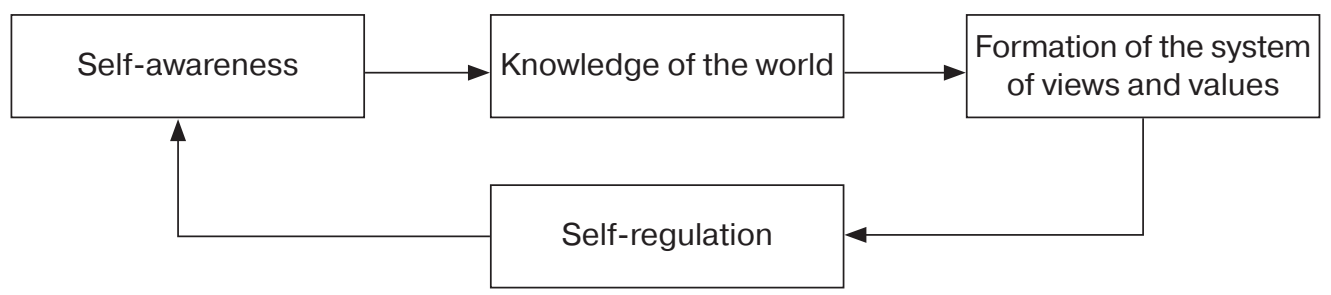

The process of formation of national consciousness of the individual 
- self-realization of the person, the maximum manifestation of his mentalcreative and moral-spiritual potential "learning from someone else and not shunning";

- awareness of national peculiarities and differences of mentality, tolerant attitude to other peoples and cultures;

- preservation of cultural and genetic code, enrichment and development of intellectual potential of the nation, reduction of "brain drain" abroad and promotion of scientific and technological progress and economic growth, achievement of high social standards;

- education of respect for the past native land, awareness of the historical role and mission of Ukrainians among other peoples of Ukraine and in the world;

- the search for answers to the question: Who are we, what kind of tribe are children, what were they and why they became so that they could and what they learned? [6]

Carrying out the archetypal analysis it is necessary to define that national consciousness of youth is an understanding and feeling of belonging to an ethnic community as result of development of culture, traditions, customs of the people. It is possible to agree with the Ukrainian researchers V. Yurchenko and Yu. Prykhodko who consider that national consciousness includes: "1) awareness of itself as the individual on the basis of representations and knowledge of the natural and biological properties, appearance ("I-nationalphysical”); 2) self-awareness as a carrier of national psychology on the basis of knowledge of the impact on mental processes, feelings, manifestation of will, mind, speech, belonging to a particular nation, people ("I-national-psychological"); 3) self-awareness as a carrier of national properties of the individual on the basis of knowledge of the dependence of their life position, attitude to reality, other people, work on national identity ("I-national-social"); 4) conscious attitude to the historical past, modern and future ethnos, nation; 5) conscious, effective attitude to the spiritual and material values of the nation and the steady need for their preservation and enhancement; 6) awareness of the individual's own responsibility for the fate of the nation, its present and future. Due to national characteristics, a person is able to preserve the continuity of traditions and customs of his people, to continue the path of its social and cultural development" [7, p. 117-118].

Formation of national consciousness, national-patriotic education of youth is inextricably linked with modern forms of youth organization, its participation in various youth organizations. The system of national-patriotic education is based on the idea of development of Ukrainian statehood as a consolidating factor in the development of society and the nation as a whole. Forms and methods of education are based on Ukrainian folk traditions, the best achievements of national and world pedagogy and psychology.

A special place in the nationalpatriotic education of young people is the youth organization "Plast". "Plast" - the national scout organization of Ukraine is a non-political and non-confessional youth organization. The purpose of the Formation is to promote comprehensive, Patriotic education and self-education of Ukrainian 
youth on conscious, responsible and aware citizens of local, national and international community, leaders of society on the ideological principles of the Formation and on the principles of Christian morality.

The first children's Ukrainian youth organization called "Plast" was created in 1911 thanks to A. Tysovskyi, which became a school of formation of national consciousness and patriotism. Tens of thousands of young patriots were brought up in this organization. To achieve educational goals "Plast" used its own unique method of education, the basic principles of which are voluntary membership in the organization, education and training through play and work, a gradual program of classes and tests, a circle system of self-organization, promotion of initiative and selfgovernment, knowledge of nature and life among nature, support of special interests and abilities of children and youth.

In summer camps, during excursions, in daily activities and communication, they learned the history of Ukraine from childhood, studied and practiced the Ukrainian language, hardened themselves physically and spiritually. The three main archetypal duties of the "Plast" member are like three pointers that should be noted by "Plast" members in historical memory, to show the "Plast" path in daily life which the "Plast" member undertakes, making a Plast oath [8, p. 34]: to be faithful to God and Ukraine, to help others, to live by the "Plast" law and to listen to the "Plast" heads.

For a long time the society was divided into those who fed the country (peasantry), and those who defended it (cossacks). This gave rise to two almost opposite forms of the archetype of consciousness on which the modern national-patriotic education of the scouts is based. The first archetype is a type of defender, warrior, mad, rampant and adventurous, intoxicating from a bachelor party, capable of affective, reckless and heroic deeds. Such Cossacks often appear in "Kobzar" of Taras Shevchenko, such they were represented by the Ukrainian and Polish romantics.

The second type of archetype of Ukrainians was determined by moderation and peacefulness, which allowed to "wait out" numerous bad weather of historical destiny. This type of consciousness found itself in a certain isolation of character, a tendency to defend against the outside world and the appeal of psychic energy to the development of inner life. One of the features of this style, that carefully avoids the imposition of the contact is a peasant habit to answer a question with a question.

An exceptional advantage of the peasant class in some periods of the Ukrainian history and also had a positive impact on the Ukrainian mentality: peasant life, which is mostly man's dependence on nature than of another person, causes high emotional experience of nature, calm, mellow disposition, elegant, tenderness, and a tendency to reflection. These features also contributed to the preservation of family and tribal groups, friendship and fraternity.

At the same time, Ukrainians have such positive features as diligence, hospitality, thirst for education, healthy optimism, courage, universality, building strong family relationships. All 
these qualities formed the basis of national-patriotic education of youth.

The Ukrainian family has traditionally been characterized by a large role of women and, above all, of the mother. With the death of her husband, she always came to the fore, became the head of the family - even when she married for the second time. The image of the mother-widow-sane, kind and at the same time strict mistress-vividly depicted in classical literature. The Ukrainian woman participated in all matters of a family not only after death of the husband, but also during his life. "The man at one corner of the hut holding and woman-three", - the proverb says. In ancient times, when patriarchal relations reigned in Europe, in Ukraine it was possible for a girl to match to a guy.

The next archetype that affects the formation of the Plast-patriot is the ideological tolerance expresses the ability of the Ukrainian people to accept into their culture the mental attitudes of other peoples and their cultures. Tolerance is an absolute value in the conditions of social and cultural pluralism in the society of competing interests, sometimes colored by national or confessional intolerance. The idea of tolerance has a symbolic content. It was born as a religious tolerance, passed its formation as a principle of optimal relations between Church and state, and finally developed as a basic principle of interpersonal and inter-group relations, mitigating differences related to ethnic and confessional affiliation, sex and age, material and social status in society [9]. No interpretation, no range of possible actions can be accepted as the only correct and absolutely indispu- table one. Tolerance is a moral imperative, an attribute of the highly moral life of mankind and, accordingly, a kind of social and moral code, with the help of which the development of civil society is measured. "The real political gift, - the famous Ukrainian philosopher S. Krymsky said on this occasion, - is the art of movement in the corridor of different voices and opinions, that is, the state of tolerance, which Aldous Hackley called the religion of our time" [10, p. 2].

The church played an important role in the formation of Ukrainian mentality and the formation of national consciousness of young people. Historically, the people's worldview of Ukrainians has three main layers: demonological, mythological and Christian. The Christian religion, which came to the Ukrainian lands at the end of the 10th century, absolutized the pre-christian hierarchy, trying not to destroy the old worldview system, but to adapt it as much as possible to its needs. The result of this confrontation of ideas was a religious dualism (dualism), elements of which are still preserved in folk customs and rituals. With the introduction of Christianity in beliefs and beliefs the element of the supernatural increases. At the same time, the fantastic and supernatural, which was not associated with the official religion, was forced into the sphere of folk tradition (poetry, fairy tales, legends and the like).

We can not say about cordo centrism - the ability to perceive the surrounding world out of the opposition, "sensual - rational" through the heart, which appears to be a special complete world, the center of physical, mental and spiritual life. It is the spirit, which 
is called the heart, that plays a leading role in the development of personality in man.

One of the main tasks of the modern "Plast" movement is the development of human potential, education of creative, thinking generation of the new formation, new leaders, reformers and statesmen. Today "Plast" movement in Ukraine is the most modern and proven technique for centuries, which allows one to form the leaders of a new generation of Ukrainians. The formation of spiritual values and universal moral qualities depends on the level of spirituality, patriotism and national consciousness for a comprehensive approach of education of a young person it is necessary to solve the following tasks:

- education and self-education of moral and cultural qualities on the principles of Christian morality;

- education of national consciousness, responsibility and belonging to the Ukrainian society;

- education of love for Ukraine and readiness for its protection, respect for the state symbols of Ukraine.

To solve these problems, it is necessary to have a set of educational activities and a system of cooperation between state institutions and the Formation, involving the media, scientists, institutions of social and cultural purpose.

From the position of the arch-typical analysis of the activity of the youth organization "Plast" is the people's mentality. It is love for the country that should be the source of spiritual strength of the citizens of Ukraine. And to be a patriot is to wish prosperity to the countrymen and the state by all means. This does not mean a negative attitude to other nations and the desire to harm them, it means caring for their people and multiplying its achievements [11]. These sincere feelings can develop Ukraine, become an engine of progress. Patriotism should be considered simultaneously in different aspects: as one of the components of social and individual consciousness, mentality, national consciousness; as a component of ideology, culture, history, psychology; as one of the highest values of society and the individual; as a direction of education; as a source of wellbeing, well-being and successful development of the most important spheres of life of society and the state.

Today "Plast" is the largest and oldest Ukrainian scout organization, which operates in many countries of the world and unites the "Plast" members of Ukraine and the diaspora, whose members are about 10 thousand people from all over Ukraine

\section{Conclusions and prospects for fur-} ther research. As we can see, the archetypal analysis proved that the raising method of education, the formation of a real citizen-a patriot of the useful world, to his people, to himself - is capable and proven by more than one generation. Thanks to the clear and precise purpose of "Plast", the three duties of the "Plast" Oath and fourteen points of the "Plast" Law; with a long process of education and self-education, knowledge, practical experience, formation of useful habits and skills; on the basis of love to the native nature (relation to nature), the people, the history of his native land, national traditions and peculiarities of their mentality; inclusive (loose) formation environment of 
growth motivation (a system of titles and samples) - a patriot-personality grows from the individual.

In further studies, special attention will be paid to the analysis of the formation of social responsibility of young people in the process of national-patriotic upbringing.

\section{REFERENCES}

1. Afonin E., Bazhal Yu., Bakumenko V. et. al. (2004). Rozvytok suspilstva [Development of society]. I. Rozputenko, B. Lesser (Eds.). Kyiv: K.I.S. [in Ukrainian].

2. Kohut O. V. (2010). Arkhetypni siuzhety y obrazy v suchasnii ukrainskii dramaturhii (1997-2007 rr.) [Archetypal plots and images in contemporary Ukrainian drama (1997-2007)]. Rivne: NUVHP [in Ukrainian].

3. Saimon H. A. (2001). Administratyvna povedinka: Doslidzhennia protsesiv pryiniattia rishen $\mathrm{v}$ orhanizatsiiakh, shcho vykonuiut administratyvni funktsii [Administrative Behavior: A Study of Decision-making Processes in Administrative Organisations]. Kyiv: ArtEK [in Ukrainian].

4. Dontsov D. (1991). Dukh nashoi davnyny [The Spirit of Our Antiquity]. Drohobych: Vidrodzhennia [in Ukrainian].

5. Kontseptsiia hromadianskoho vykhovannia osobystosti $\mathrm{V}$ umovakh rozvytku ukrainskoi derzhavnosti [Concept of civic education of the individual in the conditions of development of Ukrainian statehood]. (2003). Doshkilne vykhovannia. - Preschool education, 2, 3-8 [in Ukrainian].

6. Yurchenko V. (n.d.). Formuvannia v molodi natsionalnoi samosvidomosti odne z holovnykh zavdan osvity [Formation in the youth of national consciousness is one of the main tasks of education]. www.interklasa.pl. Retrieved from http://www.interklasa.pl/portal/ dokumenty/ridna_mowa_uk/index. php?page=rm38_02 [in Ukrainian].

7. Prykhodko Yu. O., Yurchenko V. I. (2012). Psykholohichnyi slovnykdovidnyk [Psychological dictionarydirectory]. Kyiv: Karavela [in Ukrainian].

8. Tsabaniuk I., Tarnavska O. (1991). Batkam pro Plast [For Parents on Plast]. Melburn [in Ukrainian].

9. Remenets O. (2013). Vytoky tsinnostei ukrainskoi kultury [Origins of values of Ukrainian culture]. jrnl.nau.edu.ua. http://jrnl.nau.edu.ua/index.php/VisnikPK/article/download/7487/8545. [in Ukrainian].

10. Krymskyi S. B. (2006). SNB! Fronezys [SNB! Fronesis]. Den - Day, November, 2 [in Ukrainian].

11. Artemchuk A. (n.d.). Natsionalna svidomist, hidnist i patriotyzm - shliakh do pokrashchennia dobrobutu naselennia Ukrainy [National consciousness, dignity and patriotism - a way to improve the well-being of the Ukrainian population]. ukr-ini.org.ua. Retrieved from http://ukr-ini.org.ua/ hmenu-137/4666-2327 [in Ukrainian].

\section{СПИСОК ВИКОРИСТАНИХ ДЖЕРЕЛ}

1. Розвиток суспільства: монографія / за заг. ред. І. Розпутенка, Б. Лессера; кол. авт. : Е. Афонін, Ю. Бажал, В. Бакуменко та ін. - К. : К.І.С., 2004. $-340 \mathrm{c}$.

2. Когут О. В. Архетипні сюжети й образи в сучасній українській драматургії (1997-2007 рр.) : монографія / О. Когут ; Нац. ун-т вод. госпва та природокористування. Рівне : НУВГП, 2010. - 440 c.

3. Саймон Герберт А. Адміністративна поведінка: Дослідження процесів прийняття рішень в організаціях, що виконують адміністративні 
функції / Герберт А. Саймон ; пер. 3 англ. - К. : АртЕК, 2001 - 392 с.

4. Донщов Д. Дух нашої давнини / Д. Донцов. - Дрогобич: Відродження, 1991. - 245 с.

5. Концепція громадянського виховання особистості в умовах розвитку української державності // Дошкільне виховання. - 2003. № 2. - C. 3-8.

6. Юрченко В. Формування в молоді національної самосвідомості - одне 3 головних завдань освіти [Електронний ресурс] / В. Юрченко. - Режим доступу: http://www.interklasa. $\mathrm{pl} /$ portal/dokumenty/ridna_mowa_ uk/index.php? page $=$ rm38_02

7. Приходько Ю. О. Психологічний словник-довідник / Ю. О. Приходь- ко, В. І. Юрченко. - К. : Каравела, 2012. $-328 \mathrm{c}$.

8. Цабанюк I. Батькам про Пласт / І. Цабанюк, О. Тарнавська. - Мельбурн, 1991. - 210 с.

9. Ременещь О. Витоки цінностей української культури [Електронний ресурс] / О. Ременець. - Режим доступу : http://jrnl.nau.edu. ua/index.php/VisnikPK/article/ download/7487/8545

10. Кримсъкий С. Б. СNB! Фронезис / С. Б. Кримський // День. - 2006. 14 листоп. - С. 2.

11. Артемчук А. Національна свідомість, гідність і патріотизм - шлях до покращення добробуту населення України. Українська ініціатива. - URL: http://ukr-ini.org.ua/ hmenu-137/4666-2327 